\title{
La Sapho des Lumières. Anthologie établie et présentée par Huguette Krieg
}

\section{Franco Piva}

\section{Q OpenEdition}

1 Journals

\section{Edizione digitale}

URL: https://journals.openedition.org/studifrancesi/45825

DOI: 10.4000/studifrancesi.45825

ISSN: 2421-5856

\section{Editore}

Rosenberg \& Sellier

\section{Edizione cartacea}

Data di pubblicazione: 1 octobre 2007

Paginazione: 441

ISSN: 0039-2944

\section{Notizia bibliografica digitale}

Franco Piva, «La Sapho des Lumières. Anthologie établie et présentée par Huguette Krieg», Studi

Francesi [Online], 152 (LI | II) | 2007, online dal 30 novembre 2015, consultato il 24 novembre 2021.

URL: http://journals.openedition.org/studifrancesi/45825 ; DOI: https://doi.org/10.4000/studifrancesi. 45825

Questo documento è stato generato automaticamente il 24 novembre 2021.

\section{(c)}

Studi Francesi è distribuita con Licenza Creative Commons Attribuzione - Non commerciale - Non opere derivate 4.0 Internazionale. 


\title{
La Sapho des Lumières. Anthologie établie et présentée par Huguette Krieg
}

\author{
Franco Piva
}

\section{NOTIZIA}

La Sapho des Lumières. Anthologie établie et présentée par Huguette KRIEG, Publications de l'Université de Saint Etienne Jean Monnet, 2006 («Lire le Dix-huitième Siècle»), pp. 147.

1 Il volumetto raccoglie una decina di testi che, dall'Artamène ou le grand Cyrus di Mlle de Scudéry al Sapho, drame en cinq actes et en prose di Mme de Staël, passando per i Dialogues des morts di Fontenelle e per i Nouveaux dialogues des morts di Pesselier, hanno per protagonista la celebre poetessa greca, la cui presenza, nella letteratura francese del Settecento, ha un'evidenza, e un'importanza, per alcuni versi, inattese, per altri versi, significative della complessità del secolo. «La Sapho des Lumières - fa osservare la curatrice del volume che, nella sua ricca «Présentation» ripercorre la storia del mito di Saffo fin dall'antichità e prende in particolare in esame i diversi ruoli che esso ha svolto nel secolo dei Lumi - atteste l'incomparable richesse et la vitalité du mythe littéraire légué par l'Antiquité. L'érudition du Grand Siècle avait difficilement fait la part du personnage historique, auréolé de son vivant, et de la figure mythique créée par Ovide, querelle que le xviII ${ }^{e}$ siècle poursuivit et n'a pas évidemment épuisée. Le mythe de Sapho affleure dans l'art, la littérature et la pensée philosophique. Son infléchissement, sous l'effet des hantises et des questions propres à chaque créateur, restitue un panorama vivant des enjeux esthétiques et idéologiques du siècle. Parce que le saut de Leucade appartenait au domaine des images connues et fascinantes, le XVIII ${ }^{\mathrm{e}}$ siècle lui assigne une place de choix; le mythe y gagna en profondeur, en se prêtant à des débats 
d'idées sur l'amour, le bonheur, abandon, la folie, le suicide et sur les rapports avec Dieu».

2 A leggere questi testi e le considerazioni che li accompagnano, si ha, in altri termini, l'impressione che il mito di Saffo, con i problemi interpretativi che esso pone, costituisca e funzioni come una straordinaria cartina di tornasole e che ad esso il Settecento francese ricorra per dare corpo e voce ad alcune delle istanze più controverse, quando non contraddittorie, che lo attraversano da un capo all'altro e che proprio nel mito di Saffo, o per meglio dire nelle diverse interpretazioni cui esso ha dato origine, trovano una delle loro manifestazioni più significative e convincenti. 